\title{
Spindle cell lipoma of the orbit: a case report of an unusual orbital pathology
}

\section{Tłuszczak wrzecionowatokomórkowy oczodołu - opis przypadku nietypowei patologii oczodołu}

Simone Ulivieri', Giuseppe Oliveri', Paolo Alfonso Motolese2, Mario Fruschelli², Edoardo Motolese², Felice Menicacci², Paolo Galluzzi ${ }^{3}$, Matteo Bellini ${ }^{3}$, Antonio Giorgio ${ }^{4}$, Paolo Toti $i^{5}$, Luigi Pirtoli ${ }^{6}$

\author{
1Department of Neurosurgery, University of Siena, Siena, Italy \\ ${ }^{2}$ Department of Ophthalmology, University of Siena, Siena, Italy \\ 3 Unit of Neuroradiology, University of Siena, Siena, Italy \\ ${ }^{4}$ Department of Neurological and Behavioural Sciences, University of Siena, Siena, Italy \\ ${ }^{5}$ Department of Human Pathology and Oncology, University of Siena, Siena, Italy \\ 6Unit of Radiotherapy, 'Santa Maria alle Scotte' Hospital, Siena, Italy
}

Neurologia i Neurochirurgia Polska 2010; 44, 4: 419-423

\begin{abstract}
Spindle cell lipoma is a rare and distinct variant of soft tissue tumour characterised by spindle cells in which the fat content may be scarce or absent. Most spindle cell lipomas arise as a subcutaneous mass of the neck, shoulders or back. Rarely, they can also be found in unusual sites, such as the oral cavity, larynx, bronchus, breast, and extremities. Localisation of spindle cell lipoma in the orbit has been described in a few cases. We report here on a case of an orbital mass surgically excised in an adult male and discuss the differential diagnosis with other soft tissue tumours with a lipomatous component, such as lipomatous haemangiopericytoma, a rare variant of haemangiopericytoma.
\end{abstract}

Key words: spindle cell lipoma, orbit, surgery.

\section{Introduction}

Spindle cell lipoma (SCL) was first described by Enzinger and Harvey in 1975 [1]. Several studies about

\section{Streszczenie}

Tłuszczak wrzecionowatokomórkowy jest rzadką i odrębną odmiana guza tkanek miękkich, która cechuje się obecnością komórek wrzecionowatych o małej zawartości tłuszczu lub pozbawionych tłuszczu. Większość tłuszczaków wrzecionowatokomórkowych wystęuje w postaci podskórnego guza okolicy szyi, ramion lub pleców. Rzadko spotyka się je w nietypowych lokalizacjach, takich jak jama ustna, krtań, oskrzela, sutek lub kończyny. Opisano kilka przypadków tłuszczaków wrzecionowatokomórkowych umiejscowionych w oczodole.

$\mathrm{W}$ niniejszej pracy opisano przypadek guza oczodołu u dorosłego mężczyzny leczonego chirurgicznie i omówiono różnicowanie z innymi guzami tkanek miękkich z komponentą tłuszczową, takich jak obłoniak ze zróżnicowaniem tłuszczakowatym (lipomatous haemangiopericytoma), rzadka odmiana obłoniaka.

Słowa kluczowe: tłuszczak wrzecionowatokomórkowy, oczodół, leczenie chirurgiczne.

this benign tumour have been reported since then. It is a circumscribed, mobile mass, typically arising on the posterior neck, upper back and shoulders of male adults in the fifth and seventh decade. It has also been described

Correspondence address: Simone Ulivieri, MD, Dept. of Neurosurgery, Santa Maria delle Scotte Hospital, Viale Bracci, 53100 Siena, Italy, e-mail:simone.ulivieri@katamail.com

Received: 24.11.2009; accepted: 17.05.2010 
in unusual sites, such as the oral cavity, larynx, bronchus, breast, orbit and extremities [2]. Histologically, SCL consists of a mixture of bland spindle cells and mature adipocytes and the matrix surrounding the cells is composed of varying amounts of mucoid material and collagen. Tumours showing similar morphology with SCL, such as mammary-type myofibroblastoma of extramammary soft tissue and solitary fibrous tumour-haemangiopericytoma (HPC), have been previously described [3]. It has been reported that spindle cells in SCL are positive for CD34 and generally negative for desmin.

Lipomatous HPC (L-HPC) is a very rare variant of HPC. The concept of HPC as a diagnostic entity has been controversial since 1942, when Stout and Murray first described it and introduced this term for tumours mainly composed of pericytes [4]. In recent years, criticism of HPC has been based on the recognition that a branching capillary vascular network supporting cellular spindle cell proliferation is a rather nonspecific finding present in a variety of mesenchymal neoplasms. Most masses classified in the past as HPC are now termed solitary fibrous tumours (WHO). Many pathologists acknowledge the existence of soft tissue tumours characterised by cytologically uniform spindle cells arranged in a consistent architectural pattern around a branching capillary vasculature. Although these tumours demonstrate a spectrum of ultrastructural features and a consistent but non-specific immunohistochemical staining profile (positive for vimentin and CD34), they are considered to represent a distinct clinicopathological entity and are classified as HPCs. In 1995, Nielsen et al. [5] reported on a series of three previously undescribed soft tissue tumours composed of an admixture of HPC and mature adipose tissue. They coined the term L-HPC for these singular neoplasms. Histologically, these are characterised by an admixture of benign HPC areas with mature adipose tissue. L-HPCs are surrounded by a thin, discontinuous capsule, and consist of homogeneous round cells in a prominent vascular network, and islands of mature adipocytes with a very low number of mitoses, less than 1 per 10 high power fields. Several case series have described these tumours as benign fat-containing variants of HPC, usually arising in the deep soft tissues of the leg and trunk. In both SCL and L-HPC, the possibility of a local relapse after surgery cannot be excluded, particularly if the tumour is very close to 'critical' organs, thus constraining resection. This possibility might occur for the orbit, in fact. The rare orbital localisation of solitary fibrous tumour-HPC has also been described [6].

\section{Case report}

A 46-year-old man was admitted to our hospital for the presence of a proptosis in the left eye, gradually developing during two years before referral. General physical examination did not reveal any abnormality and routine blood investigations were within normal limits. Visual acuity in the left eye was 20/40, with a partial defect of the visual field and atrophic changes in the optic disc but normal parameters on the opposite side. Ocular movements were normal and pupils were symmetric, round and reactive without evidence of a relative afferent papillary defect. There was an upward and outward 24-mm proptosis of the left eyeball with normal intraocular pressure in both eyes. Magnetic resonance imaging (MRI) of the brain revealed a welldefined circumscribed mass, pushing downwards and leftwards the globe and medial rectus muscle and with an unusual marked hyperintensity on short-TR images (T1-weighted images) and an isointensity with the orbital fat on long-TR images (FLAIR and T2-weighted images) (Fig. 1).

The tumour was surgically removed by a medial transcutaneous (Lynch) approach; no adherences of optic nerve or involvement of other adjacent structures occurred. The specimen was well circumscribed and slightly firmer than normal adipose tissue, with a yellow cut surface. The postoperative period was uneventful. A computed tomography (CT) scan revealed complete excision of the tumour (Fig. 2). Definitive histological diagnosis was SCL (Fig. 3), after an initial uncertainty in differential diagnosis between L-HPC and SCL. A recent report claimed that a significant proportion of SCL express desmin and therefore, in our case, immunoreactivity for this marker did not exclude the diagnosis of L-HPC and could not help us to differentiate these entities [7]. The patient was discharged on the third day. The opportunity for postoperative irradiation was considered in a multidisciplinary discussion, and radiotherapy was judged advisable on the grounds of the possibility of a local relapse, provided that very accurate treatment planning and radiation delivery would be performed, in order to avoid damage to the eye. Informed written consent was obtained from the patient, in this regard. Treatment started one month after surgery. The retrobulbar space of the left orbit was irradiated with a three-dimensional conformal stereotactic dynamic technique, using a micro-multileaf collimator. Total dose was $50.4 \mathrm{~Gy}$, with a standard fractionation of five sessions of $180 \mathrm{cGy}$ 

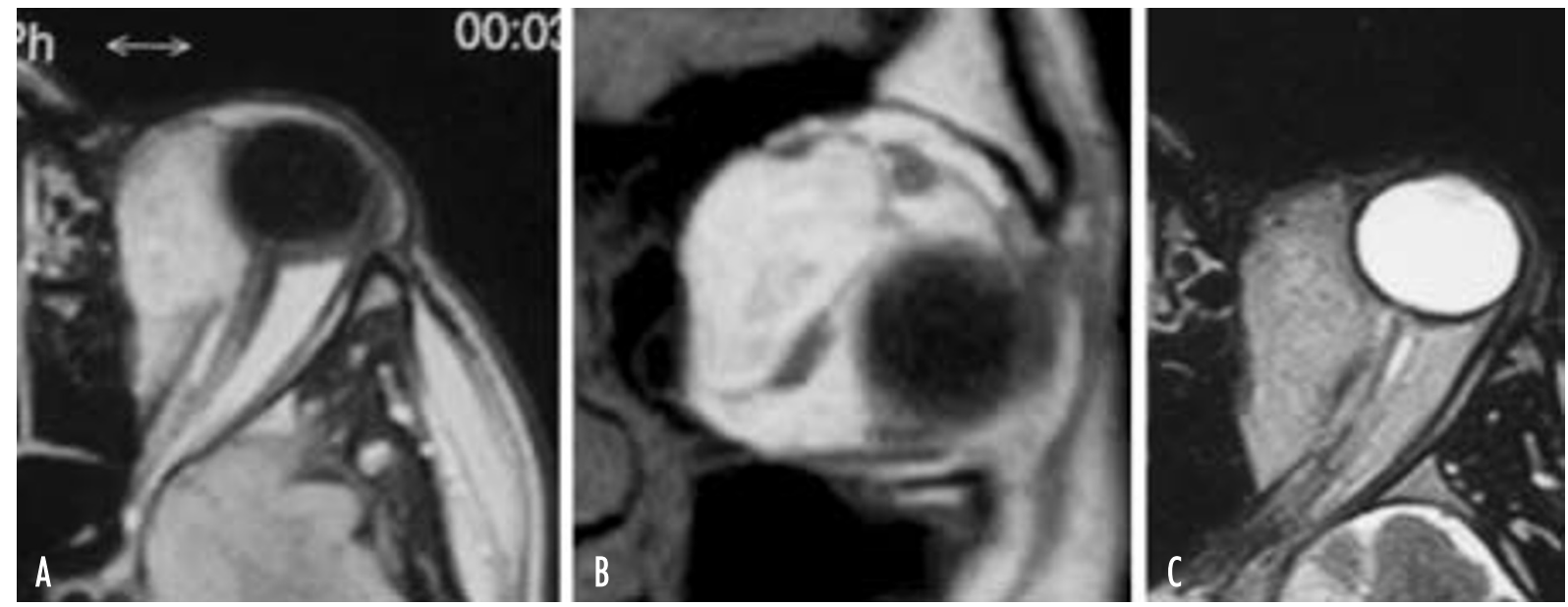

Fig. 1. Axial FLAIR (A), coronal spin-echo T1-weighted (B), and axial spin-echo T2-weighted (C) images of the left orbit showing a well-circumscribed oval mass, pushing downwards and leftwards the globe and medial rectus muscle. The mass is hypointense to the retrobulbar fat, and markedly hyperintense with respect to the extraocular muscles (due to its high fat content)

per week. The dose delivered to the eye was very low. In fact, total dose was $50.4 \mathrm{~Gy}$, with a standard fractionation of five sessions of $180 \mathrm{cGy}$ per week. After 12 months, a follow-up visit showed improvement of visual acuity in the left eye to 20/20 and MRI examination showed no sign of recurrence or post-radiotherapy damage.

\section{Discussion}

SCL is a distinct entity, which has peculiar clinicopathological and immunohistochemical features. It is a benign tumour, although containing different components. Therefore differential diagnosis can be very difficult, especially when it occurs in other than typical anatomical locations (posterior neck, back, shoulder). Typically, in light microscopy, the lesion consists of a fairly well-circumscribed but rarely encapsulated mass of mature fat cells that are separated and partly replaced by groups of small, slender spindle cells. In the present case, neoplastic growth infiltrated the extrinsic ocular muscles, and this initially led to the pathological diagnosis of L-HPC. In some cases, the proliferation of spindle cells is localised and affects only a portion of the lipomatous growth. In other cases, as in the presented one, it is diffuse and involves almost the entire lesion, often concealing the lipomatous nature of the tumour. In general, the proliferated spindle cells are of great uniformity, having a single elongated nucleus and narrow, bipolar cytoplasmic processes. The vascular pattern is usually inconspicuous and consists of fairly thick-walled

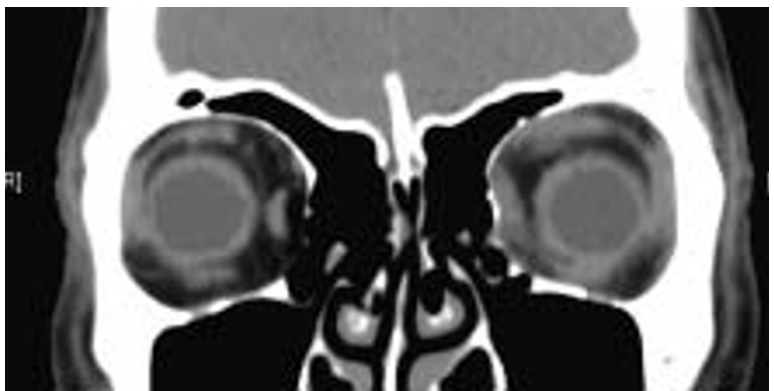

Fig. 2. Postoperative CT scan demonstrating the complete removal of the tumour

vessels of small or intermediate size, which represent the main histological clue for differential diagnosis between SCL and L-HPC. L-HPC presents a rich vascular pattern, often with peculiarities such as perivascular hyalinisation. However, the possibility that SCL also displays a HPC-like vascular pattern has been described [8].

Differential diagnosis of SCL includes myofibroblastoma and solitary fibrous tumour, which were excluded in our case due to the rich lipomatous component, and haemangiopericytoma, lipomatous variant. These lesions all share overlapping morphological features, since it is possible that they are histogenetically related. All of them display positivity for CD34, and it has been proposed that they derive from a CD34-positive perivascular stem cell with the capacity of lipocytic and fibroblastic/myofibroblastic differentiation [9]. MR appearance of orbital spindle cell lipoma may resemble that of L-HPC: both lesions appear as a well-circumscribed mass, hyperintense with respect to extraocular muscles; depending on the fat content, L-HPC may be iso- to 

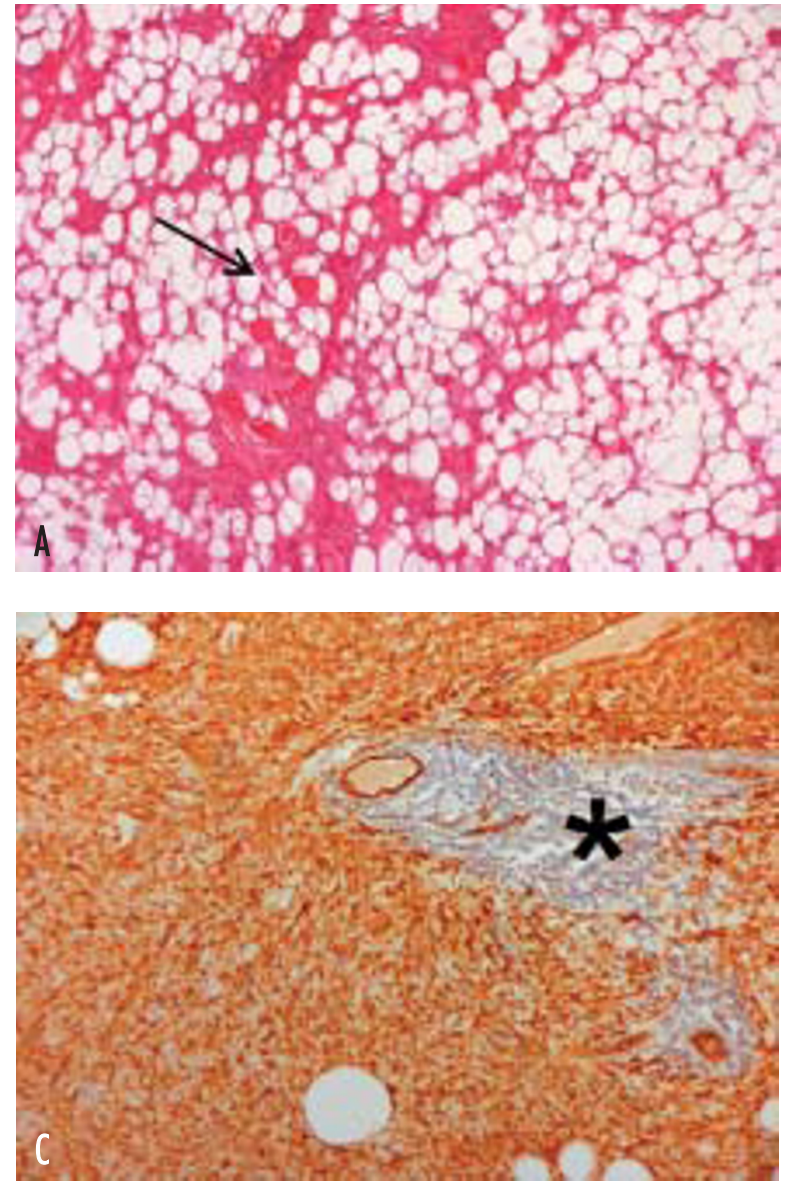

slightly hypointense in comparison with retrobulbar fat on both short- and long-TR MR images, whilst lipomas are always isointense with fat. L-HPC also appears histologically benign and reports to date suggest benign clinical behaviour. The only predictors of malignant behaviour are increased time from symptom onset to surgery, and initial incomplete excision. L-HPC is likely to be a benign tumour. However, it is difficult to draw conclusions on the long-term prognosis because of the slow growth rate, and delayed recurrence and metastasis of classical HPC. Almost all L-HPC and HPC tumours have low or absent mitotic activity: only $6 \%$ of the tumours reported had more than four mitoses per high power field. The existence of L-HPC supports the concept that soft tissue HPC is distinct from solitary fibrous tumour, since adipose tissue has never been reported as a component of solitary fibrous tumour of the pleura or any other location. In our case, although the final diagnosis was SCL, we preferred to perform complete excision and radiotherapy, taking into account that a local relapse, although unlikely, might occur. The

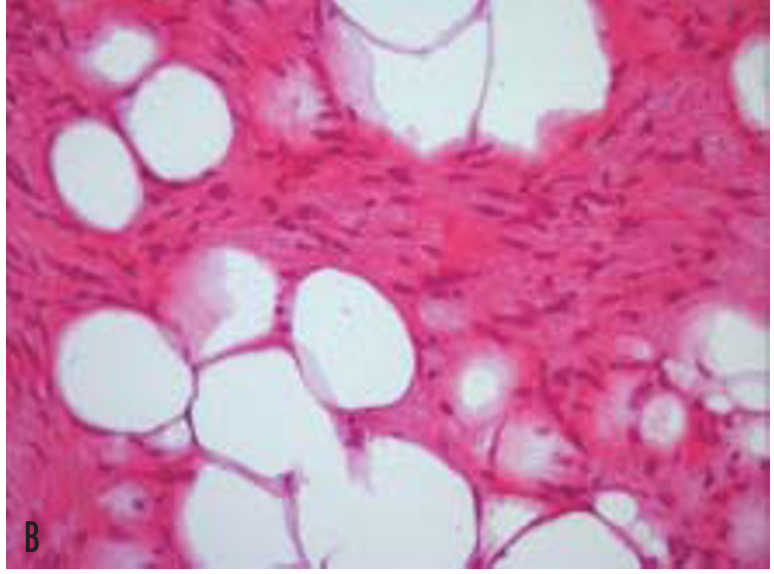

Fig. 3. (A) A lipomatous-rich area of the tumour. Arrow indicates extrinsic musculature of the orbit entrapped in the neoplasia (haematoxylin \& eosin, original magnification $40 \times$ ); (B) neoplastic cells are elongated, with poorly distinguishable cell borders and oval nuclei. The cytoplasm may show variable amounts of lipid content (haematoxylin \& eosin, original magnification 200X); (C) strong and consistent immunopositivity of the neoplastic and vascular cells. An asterisk $\left({ }^{*}\right)$ indicates an immunonegative area which is occupied by inflammatory cells, mainly lymphocytes (CD34 immunohistochemistry, original magnification $100 \times$ ) radiotherapy technique adopted in this patient (fractionated, stereotactic conformal dynamic multi-arc irradiation) provided a very low dosage to the eye and a dose of $50.4 \mathrm{~Gy}$ at the surgical bed, which is sufficient to control microscopic residual disease. However, this dose level is also safe as far as concerns damage to the optic nerve. There is considerable experience, furthermore, of safe irradiation of the retrobulbar space in benign conditions (e.g., Basedow disease), even at doses lower than in the present case.

\section{Acknowledgments}

The authors are grateful to Dr. Georgantzinou Maria for her technical assistance in the preparation of the paper.

\section{Disclosure}

Authors report no conflict of interest. 


\section{References}

1. Enzinger F.M., Harvey D.A. Spindle cell lipoma. Cancer 1975; 36: 1852-1859.

2. Daniel C.S., Beaconsfield M., Rose G.E., et al. Pleomorphic lipoma of the orbit: a case series and review of literature. Ophthalmology 2003; 110: 101-105.

3. Guillou L., Gebhard S., Coindre J.M. Lipomatous hemangiopericytoma: a fat-containing variant of solitary fibrous tumor? Clinicopathologic, immunohistochemical, and ultrastructural analysis of a series in favor of a unifying concept. Hum Pathol 2000; 31: 1108-1115.

4. Ceballos K.M., Munk P.L., Masri B.A., et al. Lipomatous hemangiopericytoma: a morphologically distinct soft tissue tumor. Arch Pathol Lab Med 1999; 123: 941-945.

5. Nielsen G.P., Dickersin G.R., Provenzal J.M., et al. A histologic, ultrastructural and immunohistochemical study of a unique variant of hemangiopericytoma. Am J Surg Pathol 1995; 19: 748-756.

6. Polito E., Tosi M., Toti P., et al. Orbital solitary fibrous tumor with aggressive behavior. Three cases and review of the literature. Graefes Arch Clin Exp Ophthalmol 2002; 240: 570-574.

7. Çomunoglu N., Çomunoglu C., Ekici A.I., et al. Spindle cell lipoma. Pol J Pathol 2007; 58: 7-11.

8. Davies P.E., Davis G.J., Dodd T., et al. Orbital lipomatous haemangiopericytoma: an unusual variant. Clin Experiment Ophthalmol 2002; 30: 281-283.

9. Weiss S.W., Goldblum J.R.. Enzinger and Weiss's Soft Tissue Tumors. $5^{\text {th }}$ ed. Mosby Elsevier, 2008; pp. 112-116.

[SPROSTOWANIE/CORRECTION]

$\mathrm{W}$ pracy The occurrence of spinocerebellar ataxia caused by dynamic mutations in Polish patients [Neurol Neurochir Pol 2010; 44 (3): 238-245] nazwisko autorki powinno brzmieć „Maria Rakowicz”, a nie „Maria Raczyńska-Rakowicz”. Wprowadzono korektę do wersji elektronicznej artykułu dostępnej na stronie www.neurologia.termedia.pl. Za błąd, niezależny od redakcji, przepraszamy.

The occurrence of spinocerebellar ataxia caused by dynamic mutations in Polish patients [Neurol Neurochir Pol 2010; 44 (3): 238-245]. The name of the author should have been "Maria Rakowicz", rather than "Maria RaczyńskaRakowicz". The electronic version of the paper at www.neurologia.termedia.pl was corrected. We apologize for that error. 